\title{
Structure of Government Support and Sustainability of SMEs in Uganda
}

\author{
Donatus Mugisha Rulangaranga (Corresponding author) \\ Department of Management Science, Makerere University Business School \\ P. O. Box 1337, Portbell Road, Nakawa, Kampala, Uganda
}

Tel: 256-700-783810Ｅ-mail: donatusmugisha2015@gmail.com

\begin{abstract}
Mellan Basemera
Department of Business Administration, Makerere University Business School

P. O. Box 1337, Portbell Road, Nakawa, Kampala, Uganda
\end{abstract}

Tel: 256-775-550405 E-mail: bridgetmellan2015@gmail.com

\begin{abstract}
Alain Vilard Ndi Isoh
Faculty of Business Management and Sustainability, ICT University, Cameroon

P. O. Box 526, Yaoundé, Cameroon
\end{abstract}

Tel: 237-71-808232Ｅ-mail: alainvilard.isoh@ictuniversity.org

Received: May 29, 2020 Accepted: June 18, 2020 Published: July 1, 2020

doi:10.5296/bms.v11i1.17103ＵRL: https://doi.org/10.5296/bms.v11i1.17103

\begin{abstract}
This study was carried out to establish whether structure of government support has any association or influence onto sustainability of SMEs in Uganda. The focus was to ascertain whether there is a link between how government provides support to SMEs and sustainability of these SMEs. A maximum sample size of 384 SMEs was selected. Questionnaire approach was used to collect data from the owners and or managers of SMEs. Based on factor analysis,
\end{abstract}


two components of structure of government support were established namely; quality of structure of government support and extent of policy implementation. To test the association of the variables, correlation analysis was carried out. The results from this analysis indicated that both components of structure of government support had significant association with SME sustainability in Uganda. Quality of structure however, had higher degree of association as compared to extent of policy implementation. Structural Equation Modeling (SEM) analysis was carried out to check the degree of influence of structure of government support onto SME sustainability. The results indicated that both components of structure of government support have influence onto SME sustainability. Based on this, it was concluded that structure of government support has a significant association with and influence onto SME sustainability in Uganda. It was therefore recommended that there was need for government support towards SMEs to be properly structured in order to realize SME sustainability. The structuring needs to take into consideration the quality of the structure as well as extent to which SME policy is implemented.

Keywords: Government support, Structure of government support, Extent of policy implementation, SME, SME sustainability

\section{Introduction}

Government is an important partner of any business that operates in a given country. Through government decision making process, policies are formulated and existing policies are nullified. This process may promote some businesses while killing some other businesses. In Rwanda for instance, when there was a ban in the sale and distribution of black polythene bags commonly known as 'kaveera', the company that engaged in the trade got significantly affected (Kardish, 2014). The same happened in Uganda when there was introduction of mobile money tax (Ampurire, 2018) and over-the-top (OTT) tax related to mobile phone internet data (Ahairwe, 2019). All these scenarios present the significance of government as an important partner in the operations of businesses in the private sector.

Small and Medium sized Enterprises (SMEs) in Uganda are categorized as entities in the private sector. This means that they too get significantly affected by the government decisions made from time to time (Bitature, 2018). One of the things that the government of Uganda has been doing in the operations of SMEs is provision of its support as government. The government has been providing support ranging from providing capital (entandikwa) to providing inputs such as farm inputs in terms of seeds and live animals for rearing and trade (Ssekamtte, 2012). Similar support was also provided to SMEs that offer services such as in the case of skilling programs in Uganda (Skills for Employment, 2011). All these efforts have been applauded over time in Uganda.

Despite the many interventions that the government of Uganda has put in place todate, there are still challenges relating to sustainability of SMEs in Uganda. The SMEs are still characterized as composing about $90 \%$ of entities operating in the private sector (Bitature, 
2018) with majority failing to celebrate their $5^{\text {th }}$ birthday (Ssewagudde, 2018). This simply means that there are as many start-ups as there are many failures. This makes Uganda one of the highly entrepreneurial countries but registering high business closure rates (failure rates) in the category of SMEs (Afunadula, 2018). This is not a good trend.

Considering that the government support has been provided overtime, it was necessary to consider how this support is provided to the SMEs in Uganda. It is basing on this that this study was carried out in order to establish whether there is any association between the structure of government support and level of sustainability of SMEs in Uganda.

\section{Literature}

Operating environment is one outstanding feature of government support (OECD, 2017). From the general perspective, government support goes beyond providing an enabling environment though presence of an enabling environment acts as a springboard on which other activities can flourish. These activities could be private or public activities (Effiom \& Edet, 2018).

In the case of small and medium enterprises (SMEs), the enabling environment that has been pointed out by researchers relates to the fiscal policy operated by a government. This is mainly through the taxation system of a country (Adeolu, 2017). Many SME managers and owners cite this aspect of taxation as a hindrance towards the operations of the SMEs. Their preference is not to be taxed and being allowed to attain some level of growth before they engage into paying taxes. Though this is the plea, chances are that it is likely not to be addressed in the short run (Schmidle, 2017).

In relation to the aspect of taxation is the regulation attached to business registration and overall operationalization of these businesses. Considering that there is no framework in existence relating to operations of SMEs in most developing countries, research indicates that these SMEs are dealt with as if they were corporations. This makes them get subjected to the regulations of these corporations. This has been challenging to the owners and managers of these SMEs (Effiom \& Edet, 2018).

The aspect of regulations has further had an impact on the aspect of financial accessibility by these SMEs (Mallett, Wapshott, \& Vorley, 2018). Most commercial banks in Uganda and other developing countries impose tight regulations on SMEs treating them as though they were corporations (UNDP, 2015). This has made many SMEs fail to access credit from commercial banks (OECD, 2017). The owners of SMEs however have had a strategy of going round this obstacle by applying for individual business loans and use the money to operate their SMEs. This way, commercial banks offer credit to individuals instead of offering the same credit to a business which is not properly structured. The challenge with this solution however is that the amount of credit advanced is small as compared to the amount that could have been accessed by a small and medium business (SME) (Wignaraja \& Jinjarak, 2015). 
Considering the challenges that have been documented in research that are attached to government support, three stand out. These are taxation, regulation challenge as well as the accessibility of credit (capital). Though this is the case, government effort has also been recognized in an attempt to improve performance of SMEs (Adeolu, 2017; Nemoto \& Koreen, 2019; OECD, 2015). In Uganda for instance, the government has been able to put in place a number of programs to support business activities. All these programs focus on providing direct support to households in different villages. The latest of these programs is the famous "wealth creation" (Manishimwe, 2017) and "youth fund" programs (Ategeka, 2018; Kyeyune, 2019). Previously, similar programs were rolled out such as "Entandikwa" (Ssekamtte, 2012) and "National Agricultural Advisory Services (NAADs)" (Okello, 2018). All these programs however have been politically motivated.

Though it is important to offer finances and other forms of agricultural inputs, the aspect of follow up of how such support is put to use is still weak. Perception of recipients of the support is also another challenge. Most of the recipients consider the support to be some form of appreciation for voting well. This further makes the well intentioned program hit a snug (Kajubu, 2014).

The different forms of support also exist in other countries of the world such as Singapore, United States of America as well as Bahrain. Most of these countries also provide financial assistance in form of loans that is repayable. This same model was adopted in Uganda through the youth fund. In Uganda however, it is limited to youths between the ages of 18 and 30. Basing on its structure therefore, it does not target SMEs but individuals (Okoth, 2019). The same challenge of follow up however exist. Cases of corruption (Mallett, Wapshott, \& Vorley, 2018) have also been cited in such financial support.

Incubation centers have also been cited as a form of support to SMEs. This however targets new startups and focuses on only idea generation (Ampurire, 2018). This is the initial stage of entrepreneurship. In Uganda, a similar support exists through the different public universities (Kyambogo University, 2017; Njuguna, 2016; Ruforum Communication, 2019; Nayiga, 2019; Outbox, 2019). There is also a program of Skilling Ugandans that focuses mainly on provision of skills to those that want to do business. It has been rolled out under the Uganda Skills Development Project (USDP) and referred to as Business, Technical and Vocational Education and Training (BTVET) (Skills for Employment, 2011). It has however suffered criticism related to quality of skills provided as well as relevance of the training provided towards economic growth (Okumu, 2017). It is however still being provided in the country (Uganda).

Basing on the different forms of support, the aspect of structuring government support towards SMEs is hardly cited. This raises a question as to whether it could be useful in the case of SMEs (Baldock \& Mason, 2015; Mohamad, 2019). In places where the structuring of government support was attempted, though not fully, some positive results were noticed. This has been documented in Sri-Lanka (Wickramatilake, 2018; Ministry of Industry and Commerce of Sri-Lanka, 2017), Malaysia (Jauriyah, Ismail, Sarkawi, Jaaffar, \& Rahim, 


\section{Mllinstitute"mk}

2017), Singapore (Chermaine, 2018), Kingdom of Saudi Arabia (Jeddah Chamber, 2016) as well as Silicon Valley in the United States of America (USA) (Atkinson, 2012; Preiss, 2018). Basing on the cases of these countries, a hint is given in relation to structuring government support towards SMEs. However, in places like Uganda where the structuring has not yet been in existence, planning is important to realize the desired output that comes with the structuring of government support.

\section{Hypotheses and conceptual framework}

Basing on the review of literature conducted, hypotheses were derived for testing. These hypotheses focus on the structure of government support towards SMEs in Uganda. The hypotheses are summarized below.

\section{$H_{1}$ : There is a relationship between quality of structure of government support and sustainability of SMEs in Uganda \\ $\mathrm{H}_{2}$ : There is a relationship between extent of policy implementation and sustainability of SMEs in Uganda.}

Basing on the hypotheses generated, a conceptual model was formulated to visually hypothesize the relationships to be tested. This is presented in Figure 1 below.

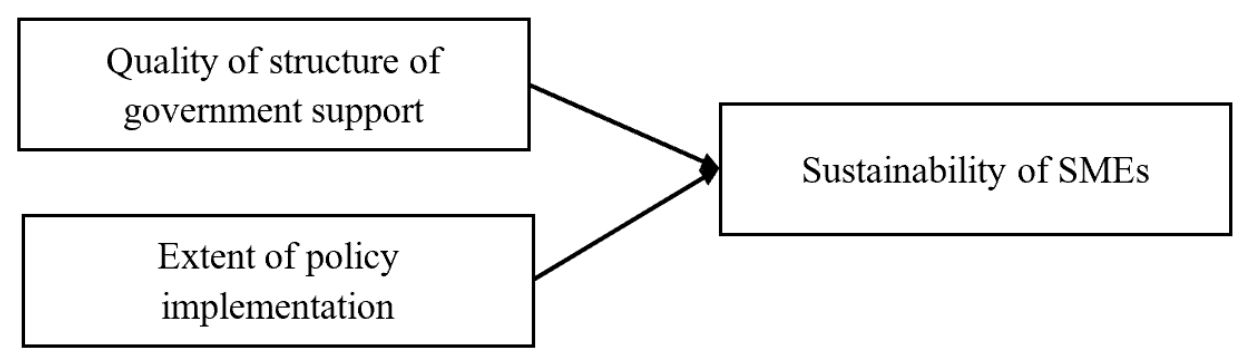

Figure 1. Conceptual framework

\section{Methodology}

This research was carried out with a focus on cross-sectional research design with a bias on quantitative methods. A specific period of time spanning from 2018 to 2020 was considered when conducting the survey for the study. This was the reason for focusing on cross-sectional research study.

Considering the nature of SMEs in Uganda, the actual population was considered to be too large. This is acceptable in quantitative studies where population size is considered to be infinite or unknown (Krejcie \& Morgan, 1970). Basing on this population, the largest possible sample size was considered. This was a sample of 384 SMEs operating in Uganda. 
A cluster sampling approach was considered when selecting SMEs to be included in this study. This was done at two different levels; the first level of clustering was based on geographical location while the second level of clustering was based on the focus of operations of SMEs. When dealing with the geographical location, emphasis was put in the central region because most SMEs operate there. This was done with an intention of ensuring that an exhaustive set of SMEs is obtained for inclusion in this study.

A questionnaire form was the only data collection tool that was used. This was done within the survey method of data collection. Combination of research administered and self-administered questionnaire approaches were practiced in the survey. This was necessary to cater for literate and illiterate respondents that were selected to form the sample (Kabir, 2016).

Before engaging in mass data collection exercise, the questionnaire was tested for validity and reliability (Taber, 2017). The results obtained in the pilot study mirrored those obtained in the final analysis. Other tests conducted to refine the variables were Explanatory Factor Analysis, Composite Reliability, Average Variance Extracted and Confirmatory Factor Analysis (Farrell \& Rudd, 2009). The results of these tests were considered before passing the variables as refined variables.

After refining the variables, the tests of hypotheses generated were done. The hypotheses were tested using correlation and Structural Equation Modeling (SEM) analyses. Correlation analysis was done to check the degree of association between the variables (IVs and DVs) while the SEM analysis was carried out to check the influence of IVs on DV.

\section{Findings}

The findings are based on the different analyses conducted. They are of both categories; those that relate to testing hypotheses as well as those that relate to refining variables. The first section of findings relates to the latter type of analyses while the second section of findings relates to the former type of analyses.

\subsection{Tests to refine the variables}

\section{a) Explanatory factor analysis}

This was carried out to check whether the factors that were theorized were the same factors that the respondents managed to point out. Use of factor loadings was considered with a cutoff point of 0.4 (Samuels, 2017). The EFA conducted generated two factors; Quality of structure of government support and Extent of policy implementation. The results of this analysis are presented in Table 1 and Table 2. 
Table 1. Factor loadings - Quality of structure of government support

\begin{tabular}{|l|l|}
\hline Question items & Factor loadings \\
\hline I am sure of getting a government contract if I apply for one & .803 \\
\hline $\begin{array}{l}\text { I have ever supported my business using findings from research } \\
\text { conducted by the Uganda Investment Authority (UIA) }\end{array}$ & .760 \\
\hline $\begin{array}{l}\text { There are specific government contracts that are preserved for local } \\
\text { organizations like my business (i.e international organizations are not } \\
\text { allowed to apply) }\end{array}$ & .729 \\
\hline $\begin{array}{l}\text { My organization has access to business loans guaranteed by the } \\
\text { government of Uganda }\end{array}$ & .698 \\
\hline $\begin{array}{l}\text { Officials from Uganda National Bureau of Standards (UNBS) often } \\
\text { visit my organization to ascertain standard of my products/services }\end{array}$ & .676 \\
\hline
\end{tabular}

Table 2. Factor loadings - Extent of policy implementation

\begin{tabular}{|l|l|}
\hline Question items & Factor loadings \\
\hline $\begin{array}{l}\text { Existence of my organization has been supported by the business } \\
\text { incubation initiative of Uganda }\end{array}$ & .808 \\
\hline $\begin{array}{l}\text { Directorate of Micro, Small and Medium Enterprises (MSME) has } \\
\text { ever provided assistance to our organization }\end{array}$ & .764 \\
\hline $\begin{array}{l}\text { Uganda Investment Authority (UIA) has ever provided assistance } \\
\text { (financial or otherwise) to my organization }\end{array}$ & .713 \\
\hline $\begin{array}{l}\text { My organization has ever received assistance from government } \\
\text { through the Ministry of Trade, Industry and Cooperatives (MTIC) }\end{array}$ & .696 \\
\hline $\begin{array}{l}\text { Enterprise Uganda (EU) has ever provided assistance (financial or } \\
\text { otherwise) to my organization }\end{array}$ & .671 \\
\hline $\begin{array}{l}\text { I have ever participated in a meeting organized by a government office } \\
\text { to discuss the issues of SMEs }\end{array}$ & .584 \\
\hline
\end{tabular}




\section{Macrothink}

Business Management and Strategy

ISSN 2157-6068

2020, Vol. 11, No. 1

Findings in Tables 1 and 2 indicate that all the items that were maintained after the EFA had a factor loading above 0.4. It was on this basis that the factors were considered for further analysis aimed at refining them further.

\section{b) Reliability and validity tests}

These tests were conducted with an intention of establishing whether the data collection tool and questions therein passed the reliability and validity tests. The results are presented in Table 4.

Table 4. Reliability and Validity test results

\begin{tabular}{|l|r|r|l|}
\hline Variable & AVE & CR & CAC \\
\hline Quality of structure & 0.540 & 0.854 & 0.849 \\
\hline Extent of policy implementation & 0.504 & 0.858 & 0.826 \\
\hline Sustainability of SMEs & 0.603 & 0.911 & 0.801 \\
\hline Cut-off points & $\mathbf{0 . 5 0 0}$ & $\mathbf{0 . 7 0 0}$ & $\mathbf{0 . 5 0 0}$ \\
\hline
\end{tabular}

Key to the codes:
AVE - Average Variance Extracted
CR - Composite Reliability
CAC - Cronbach's Alpha Coefficient

Results from reliability and validity tests indicate that all the variables were considered to be valid and reliable. The question items passed convergent validity test (AVE and CR). The consistency of the responses was also considered to be reliable (CAC).

c) Confirmatory factor analysis

Basing on the results of tests conducted at this point, there was a need to confirm the factors that were extracted during the EFA and tested for validity and reliability. This was done by conducting a confirmatory factor analysis. The results of this analysis are presented in Table 5 . 


\section{Macrothink}

Table 5. Results from confirmatory factor analysis

\begin{tabular}{|l|c|}
\hline CFA measure & Structure of government support \\
\hline CMIN/DF & 3.445 \\
\hline GFI & 0.939 \\
\hline AGFI & 0.892 \\
\hline RMSEA & 0.088 \\
\hline
\end{tabular}

The results presented in Table 5 indicate that both variables were refined and appropriate for consideration to the next level of analysis. One thing to note here is that "Structure of government support" is a construct comprised of two variables; 'quality of structure' and 'extent of policy implementation'.

In line with the results of CFA, a structural model was developed. This presents a diagrammatic view of the items that were retained after the CFA. This is shown in Figure 2 below.

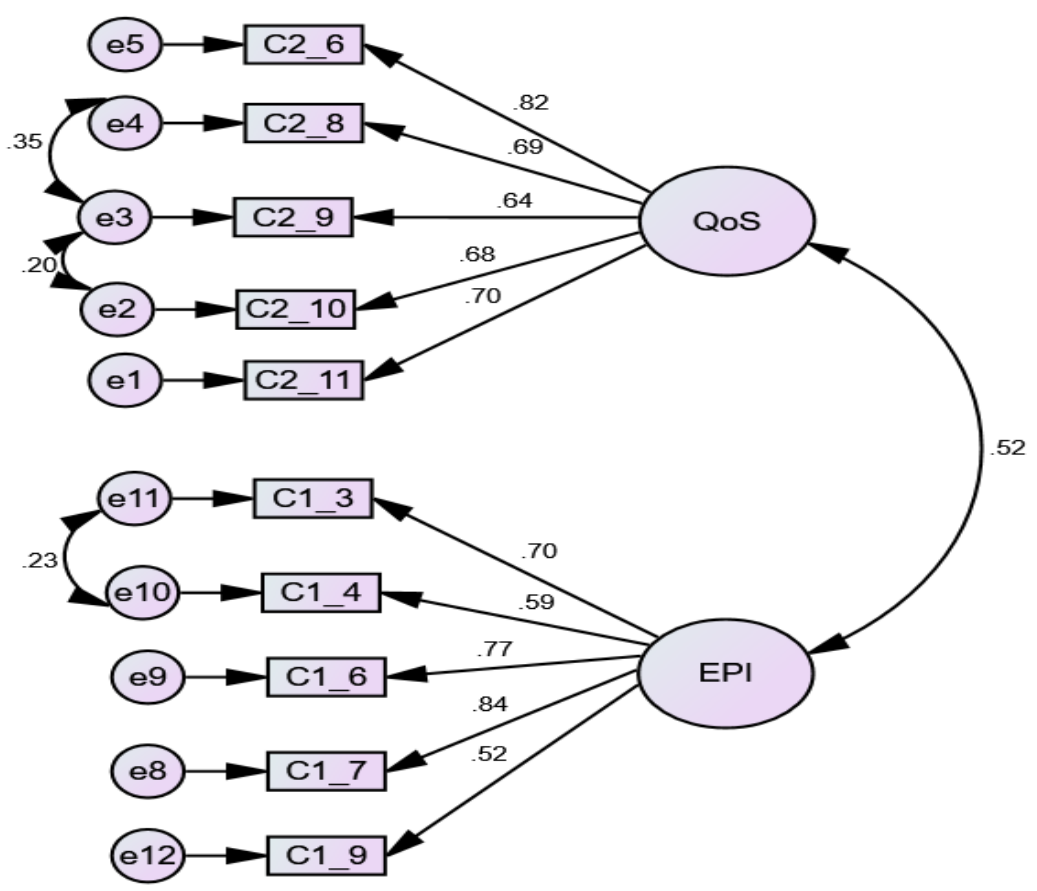

Figure 2. A CFA Model (Structural Model) for Structure of Government Support

Note:

QoS - Quality of Structure of Government Support

EPI - Extent of Policy Implementation 


\section{MInstitute Macrothink $_{\text {Int }}$}

Information in Figure 2 helps to augment information presented in Table 5. Based on information in Table 5, there was a good model fit as indicated by CMIN/DF, GIF and AGIF. The RMSEA is slightly above the threshold of 0.08 though it is still acceptable (Hooper, Coughlan, \& Mullen, 2008; MacCallum, Browne, \& Sugawara, 1996). These results are augmented by the results in Figure 2 which indicate that all the items for each of the variables had factor loadings above 0.5. This indicates that the item loads were good enough for consideration in this study. Based on the results of CFA, the final variables were formulated for consideration in the phase of hypothesis testing.

\subsection{Tests of hypotheses}

Two analyses were carried out to test the hypotheses. These are correlation and Structural Equation Modeling (SEM) analyses. They are explained in the subsections that follow.

\section{a) Correlation analysis}

This was carried out in order to test the degree of association between the independent and dependent variables. The results from the analysis are presented in Table 6.

Table 6. Correlation Results - Structure of Government Support and SME sustainability

\begin{tabular}{|l|c|c|c|}
\hline & $\mathbf{1}$ & $\mathbf{2}$ & $\mathbf{3}$ \\
\hline Quality of structure (1) & 1 & & \\
\hline Extent of policy implementation (2) & $.400^{* *}$ & 1 & \\
\hline Sustainability of SMEs (3) & $.287^{* *}$ & $.233^{* *}$ & 1 \\
\hline
\end{tabular}

**. Correlation is significant at the 0.01 level (2-tailed).

Results from correlation analysis indicate that both variables representing structure of government support have a significant association with sustainability of SMEs in Uganda. Quality of structure however, has a higher level of association $(r=0.287 ; p \leq 0.01)$ with SME sustainability as compared to Extent of Policy Implementation $(r=0.233 ; p \leq 0.01)$. This means that both, quality of structure and extent of policy implementation have a significant association with sustainability of SMEs in Uganda. The enhancement of sustainability of SMEs is therefore associated with the enhancement of quality of structure of government support as well as extent of policy implementation by government relating to SMEs.

b) Structural Equation Model (SEM) Analysis

This was carried out with an intention of establishing the degree of influence of the independent variables onto dependent variable. The extent to which the data fits the theory that was tested was also established as part of the output of the SEM analysis. 
Model specification - SEM analysis;

$$
\begin{aligned}
& B S=f(Q o S, E P I) \\
& B S=\alpha+\beta_{1} Q o S+\beta_{2} E P I+e \ldots \ldots \ldots \ldots \ldots \ldots \ldots \ldots \ldots \ldots \ldots \ldots \ldots \ldots \ldots \ldots \\
& B S=\alpha+\beta_{1} Q o S+e_{1} \ldots \ldots \ldots \ldots \ldots \ldots \ldots \ldots \ldots \ldots \ldots \ldots .1 .1
\end{aligned}
$$

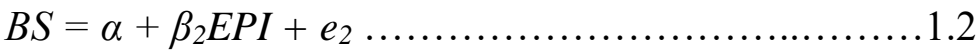

Where; [BS $\rightarrow$ SME Sustainability], [QoS $\rightarrow$ Quality of Structure of Government Support], $\left[\right.$ EPI $\rightarrow$ Extent of Policy Implementation], $\left[e_{1}\right.$ and $e_{2} \rightarrow$ error terms for paths (1) and (2)] while $\left[\beta_{1}\right.$ and $\beta_{2} \rightarrow$ Path coefficients]. The priori expectation $\rightarrow \beta_{1}>0 ; \beta_{2}>0$; as shown in

\begin{tabular}{|c|c|c|c|c|}
\hline $\mathbf{N}$ & Variables & Measurement & Expected Impact & A priori \\
\hline & \multicolumn{4}{|l|}{ Dependent Variable } \\
\hline & $\begin{array}{l}\text { Sustainability of } \\
\text { SMEs (BS) }\end{array}$ & $\begin{array}{l}\text { Five point Likert Scale } \\
\text { with coding grading from } \\
\text { strongly disagree to } \\
\text { strongly agree }\end{array}$ & & \\
\hline & \multicolumn{4}{|c|}{ Independent Variables } \\
\hline 1 & $\begin{array}{ll}\text { Quality } & \text { of } \\
\text { Structure } & \text { of } \\
\text { Government } & \\
\text { Support (QoS) } & \end{array}$ & $\begin{array}{l}\text { Five point Likert Scale } \\
\text { with coding grading from } \\
\text { strongly disagree to } \\
\text { strongly agree }\end{array}$ & + & $\beta_{1}>0$ \\
\hline 2 & $\begin{array}{l}\text { Extent of Policy } \\
\text { Implementation } \\
(\mathrm{EPI})\end{array}$ & $\begin{array}{l}\text { Five point Likert Scale } \\
\text { with coding grading from } \\
\text { strongly disagree to } \\
\text { strongly agree }\end{array}$ & + & $\beta_{2}>0$ \\
\hline
\end{tabular}
Table 7:

Table 7. Measurement of variables and expected relationships 
Based on the model specified, the analysis was carried out. The results from the analysis are presented in Table 8.

Table 8. SEM Output - Structure of Government Support onto SME Sustainability

\begin{tabular}{|l|l|l|r|r|r|r|r|r|}
\hline \multicolumn{2}{|c|}{ Variables } & Est 1 & S.E. & C.R. & P & Est 2 & Decision \\
\hline SME_Sus & $<---$ & QoS & 0.510 & 0.109 & 4.668 & $* * *$ & 0.480 & Accepted \\
\hline SME_Sus & $<---$ & EPI & 0.269 & 0.100 & 2.681 & 0.007 & 0.218 & Accepted \\
\hline \multicolumn{1}{c}{ CMIN/DF: 2.659} & AGFI: 0.904 \\
GFI: 0.940 & RMSEA: 0.073
\end{tabular}

\section{Where;}

$$
\begin{aligned}
& \text { QoS }- \text { Quality of Structure of Government Support } \\
& \text { EPI } \quad \text {-Extent of Policy Implementation } \\
& \text { SME_Sus - Sustainability of SMEs } \\
& \text { Est } 1 \quad-\text { Unstandardized Regression Weights } \\
& \text { Est } 2-\text { Standardized Regression Weights }
\end{aligned}
$$

The results indicate that both independent variables (Quality of Structure of Government Support and Extent of Policy Implementation) have significant influence onto SME Sustainability in Uganda. Both Un-standardized and Standardized Estimates indicate that Quality of Structure of Government Support has a higher influence onto SME Sustainability as compared to Extent of Policy Implementation.

The model fit indices indicate that the data managed to have a good fit of the theory that was tested. The key indices of CMIN/DF, GFI, AGFI and RMSEA are within the acceptable range. This further validated the model that was used in this study. The results are therefore relevant in providing explanation of the theory that was tested in this study.

Together with the statistical results, a structural equation model was generated. This is presented in Figure 3 below. 


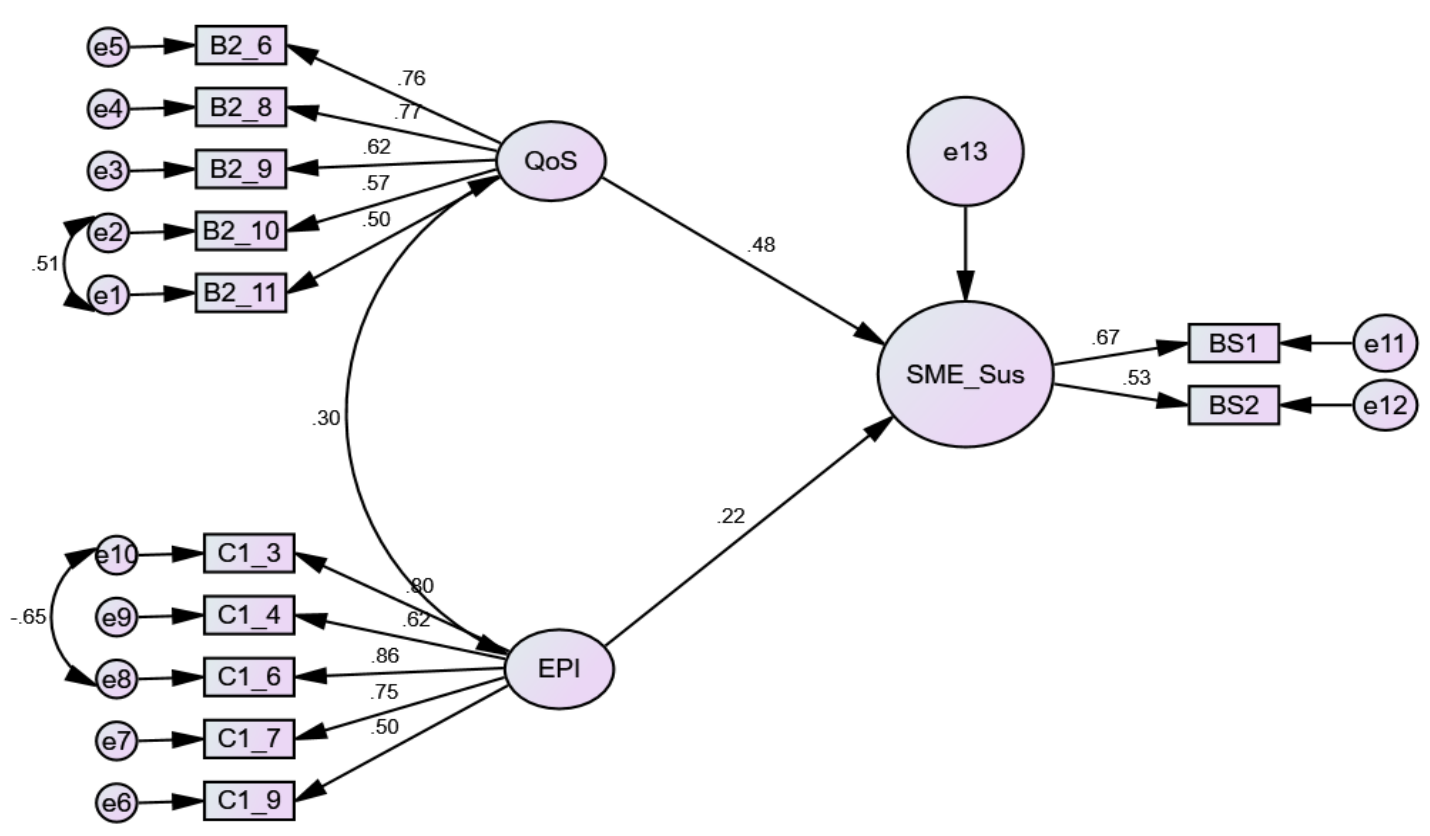

Figure 3. SEM Output - Structure of Government Support on SME Sustainability

Information presented in Figure 3 augments the results presented in Table 8. Based on the model (Figure 3), Quality of Structure of Government Support as well as Extent of Policy Implementation are indicated as not being the only variables that explain the SME sustainability in Uganda. Existence of the error term signifies that there are other variables that have influence onto SME sustainability but were not considered in this study. This is an area that shall be considered in the subsequent research studies in this subject area.

\section{Discussions, conclusion and recommendations}

Considering the rationale for conducting this research, it is important to note that structuring government support is quite important to the operations and sustainability of SMEs in Uganda. Ideally, SMEs in Uganda operate in the category of private sector. Their operations however, cannot be free of interventions from government (Eton, Mwosi, Ebong, \& Ogwel, 2019) through its organs such as Uganda Investment Authority (UIA) and Private Sector Foundation Uganda (PSFU) among others. It is through such government organs (departments) that the government support is channeled (OECD, 2018).

Though the support is there, the results indicate that it needs to be structured. When it is structured, it will have more influence onto the level of sustainability of SMEs. This structuring is likened to conducting proper diagnosis to a patient. In this analogy, a patient is the SME and a doctor is the government. If these SMEs need to be sustainable, they need to be able to receive appropriate support depending on the need. This is however a challenge when the needed support is not structured bringing about confusion on the side of the 
recipient.

Quality of a structure is one of the components of the structure of government support. This mainly focuses on how best the government organizes its different organs and or departments that directly deal with SMEs in such a way that they provide the needed support when it is needed. For instance, SMEs in Uganda have been demanding to have specific contracts reserved for them in order to boost their performance and overall existence (Bitature, 2018). The preparedness of the government organs to make this happen reflects the quality of structure.

The findings from the analysis conducted indicate that the more prepared government organs are in the desire to offer relevant services to SMEs, the more they will be in position to enhance sustainability levels of these SMEs. This therefore means that quality of structure of government support in Uganda needs to be enhanced in order to realize improvement in the level of sustainability of SMEs.

Relating to the extent of policy implementation, there is need for the different government departments to work hard to implement the policy related to operations of SMEs in Uganda. Though this may sound similar to quality of structure, the two are different. The government department (and or organs) may be prepared in terms of quality of the structure but fail to implement the policy documented to enhance operations of SMEs and hence their sustainability (Commonwealth Secretariat, 2010; Ategeka, 2018). This therefore necessitated the need to check the level of implementation of policy related to SMEs in this study. The findings indicate that indeed, there is need to ensure that the implementation levels of SME policy are tracked from time to time. When this is done, it would be possible to establish how to further improve the implementation levels of SME policy in order to enhance the level of sustainability of SMEs in Uganda.

\section{References}

Adeolu, A. M. (2017). Improving the Institutional Environment for SME Success in Nigeria. Retrieved Aug 25, 2019, from SSRN https://papers.ssrn.com/sol3/papers.cfm?abstract_id=2915002. https://doi.org/10.2139/ssrn.2915002

Afunadula, B. (2018). Current mortality rate of SMEs will kill private sector - Economist warns. Retrieved May 20, 2020, from PML Daily: https://www.pmldaily.com/business/2018/05/current-mortality-rate-of-smes-will-kill-privatesector-economist-warns.html

Ahairwe, P. E. (2019). OTT tax: The good and bad side. Retrieved May 20, 2020, from Daily Monitor publications: https://www.monitor.co.ug/OpEd/Letters/OTT-tax-good-and-bad-side/806314-5186554-kh57 bk/index.html

Ampurire, P. (2018). 420 entrepreneurs graduate from Stanbic Bank's Business Incubator. 
Retrieved Sept 20, 2019, from Softpower News: https://www.softpower.ug/420-entrepreneurs-graduate-from-stanbic-banks-business-incubator /

Ampurire, P. (2018). Telecom companies effect 0.5\% tax on mobile money withdrawals. Retrieved May 20, 2020, from Soft Power News: https://www.softpower.ug/telecom-companies-effect-0-5-tax-on-mobile-money-withdraws/

Ategeka, J. (2018). Youth Livelihood Program: Good initiative, little or no impact. Retrieved Sept 15, 2019, from New Vision: https://www.newvision.co.ug/new_vision/news/1488994/youth-livelihood-program-initiativelittle-impact

Atkinson, R. D. (2012). How the Government Built Silicon Valley-Why is government support a necessary ingredient to building a vibrant system of innovation? Retrieved Sept 20, 2019, from The Globalist: https://www.theglobalist.com/how-the-government-built-silicon-valley/

Baldock, R., \& Mason, C. (2015). Establishing a new UK finance escalator for innovative SMEs: the roles of the Enterprise Capital Funds and Angel Co-Investment Fund. Venture Capital - An International Journal of Entrepreneurial Finance, 59-86. https://doi.org/10.1080/13691066.2015.1021025

Bitature, P. (2018). Let us give SMEs a chance. Retrieved May 20, 2020, from The New Vision: https://www.newvision.co.ug/new_vision/news/1480600/us-smes-chance

Chermaine. (2018). 6 useful Government Grants and Schemes for SMEs in 2018. Retrieved Sept 18, 2019, from Open Spft: https://www.opensoft.com.sg/6-useful-government-grants-schemes-smes-2018/

Commonwealth Secretariat. (2010). Improving SMEs Access to the Public Procurement Market. London: Trade, Enterprise \& Agricultural Department of Commonwealth Secretariat.

Effiom, L., \& Edet, S. E. (2018). Success of Small and Medium Enterprises in Nigeria: Do Environmental Factors Matter? Journal of Economics and Sustainable Development, 9(4), $117-125$.

Eton, M., Mwosi, F., Ebong, C. D., \& Ogwel, P. B. (2019). Government interventions in supporting SME growth in Lira district, northern Uganda. International Journal of Emerging Research \& Development .

Farrell, A. M., \& Rudd, J. M. (2009). Factor analysis and discriminant validity: A brief review of some practical issues. OAI.

Hooper, D., Coughlan, J., \& Mullen, M. R. (2008). Structural Equation Modelling: Guidelines for Determining Model Fit. Electronic Journal of Business Research Methods, $6(1), 53-60$.

Jauriyah, S., Ismail, N. A., Sarkawi, M. N., Jaaffar, A. R., \& Rahim, N. F. (2017). 
Government Business Support Service (GBSS) and SMEs Performance: Observations from Malaysian Manufacturing. International Journal of Economic Research.

Jeddah Chamber. (2016). Small Medium Enterprises in Saudi Arabia Report, 2016. Jeddah 21431: www.jcci.org.sa.

Kabir, S. M. (2016). Preparing questionnaire. In Basic Guidelines for Research: An Introductory Approach for All Disciplines. Chittagong-4203, Bangladesh: Book Zone Publication.

Kajubu, E. (2014). Operation Wealth Creation Program Comes Under Criticism In Kabarole. Retrieved Sept 18, 2019, from Uganda Radio Network: https://ugandaradionetwork.com/story/operation-wealth-creation-program-comes-under-critic ism-in-kabarole

Kardish, C. (2014). How Rwanda Became the World's Unlikely Leader in Plastic Bag Bans. Retrieved 20, 2020, from Governing: https://www.governing.com/topics/transportation-infrastructure/gov-rwanda-plastic-bag-ban. html

Krejcie, \& Morgan. (1970). Sampling table for determination of sample size basing on pre-determined population size.

Kyambogo University. (2017). Kyambogo University To Launch Bakery And Business Incubation Center. Retrieved Sept 15, 2019, from New Vision: https://www.newvision.co.ug/digital_assets/42580303-2c76-4dd2-9162-55151eca35f3/ST1N V131217.p12.pdf

Kyeyune, M. (2019). Youth Livelihood Fund now transferred to State House. Retrieved Sept 15, 2019, from Daily Monitor: https://www.monitor.co.ug/News/National/Youth-Livelihood-Fund-now-transferred-to-StateHouse/688334-5076778-movaoa/index.html

MacCallum, R., Browne, M., \& Sugawara, H. M. (1996). Power Analysis and Determination of Sample Size for Covariance Structure Modeling. Psychological Methods, 130 - 149. https://doi.org/10.1037/1082-989X.1.2.130

Mallett, O., Wapshott, R., \& Vorley, T. (2018). Understanding the firm-level effects of regulation on the growth of SMEs. London: Department of Business, Energy and Industrial Strategy.

Manishimwe, W. (2017). Kisoro residents tipped on OWC programme. Retrieved Sept 15, 2019, from New Vision: https://www.newvision.co.ug/new_vision/news/1443510/kisoro-residents-tipped-owc-progra mme

Ministry of Industry and Commerce of Sri-Lanka. (2017). National Policy Framework for 
Small and Medium Enterprise (SME) Development. MIC.

Mohamad, M. (2019). Govt allocating significant resources to support SMEs. Retrieved 09 10, 2019, from The Online: https://www.thestar.com.my/business/business-news/2019/05/02/govt--allocating-significantresources-to-support-smes

Nayiga, T. T. (2019). Makerere launches Food Technology and Business Incubation Centre Phase II. Retrieved Sept 20, 2019, from PML Daily: http://www.pmldaily.com/news/2019/07/makerere-launches-food-technology-and-business-in cubation-centre-phase-ii.html

Nemoto, N., \& Koreen, M. (2019). SME Policy faced with Development of Financial Technology - Digital Innovation Can Improve Financial Access for SMEs. T20Japan. Retrieved from https://t20japan.org/wp-content/uploads/2019/03/t20-japan-tf9-1-digital-innovation-improvefinancial-access-smes.pdf

Njuguna, P. (2016). Sourcing for a startup incubator. Retrieved Sept 15, 2019, from Daily Monitor:

https://www.monitor.co.ug/Business/Prosper/Sourcing-startup-incubator/688616-3225286-15 q220w/index.html

OECD. (2015). Youth Entrepreneurship Support in Polland - Rapid Policy Assessments of Inclusive Entrepreneurship Policies and Programmes. European Commission.

OECD. (2017). Enhancing the Contributions of SMEs in a Global and Digitalised Economy. OECD Council.

OECD. (2018). Private Sector Engagement through Development Co-operation in Uganda. Global partnership for effective development co-operation.

Okello, L. (2018). Contribution of NAADS programme to rural farmers in Bukedea District. Retrieved Sept 15, 2019, from Makerere University: http://makir.mak.ac.ug/handle/10570/7253

Okoth, C. (2019). New study supports loans for youth empowerment. Retrieved Sept 20, 2019, from New Vision: https://www.newvision.co.ug/new_vision/news/1504362/study-supports-loans-youth-empow erment

Okumu, M. I. (2017). BTVET reform incompleteness hurting holistic skills development. Retrieved Sept 15, 2019, from New Vision: https://www.newvision.co.ug/new_vision/news/1462875/btvet-reform-incompleteness-hurtin g-holistic-skills-development

Outbox. (2019). NSSF to support local early stage businesses with funding to grow. 
Retrieved Sept 15, 2019, from Outbox: https://outbox.co.ug/outbox-stories/nssf-support-local-early-stage-businesses-funding-grow

Preiss, A. (2018). Tech Companies Supported by the Federal Government Should Share Profits With Workers, New CAP Proposal Says. Retrieved Sept 15, 2019, from Centre for American Progress: https://www.americanprogress.org/press/release/2018/04/19/449893/release-tech-companiessupported-federal-government-share-profits-workers-new-cap-proposal-says/

Ruforum Communication. (2019). Collaboration for youth business incubation: Bishop Stuart University partners with PUM Netherlands. Retrieved Sept 20, 2019, from RUFORUM:

https://ruforum.wordpress.com/2019/06/28/collaboration-for-youth-business-incubation-bish op-stuart-university-partners-with-pum-netherlands/

Samuels, P. (2017). Advice on Exploratory Factor Analysis. Centre for Academic Success.

Schmidle, C. (2017). SMEs will succeed through simple, clear and consistent rules. Retrieved Aug 20, 2019, from The EU's Assembly of Regional and Local Representatives: https://cor.europa.eu/en/news/Pages/smes-succeed.aspx

Skills for Employment. (2011). Skilling Uganda: BTVET Strategic Plan 2011-2020. Retrieved Sept 20, 2019, from SKILLS FOR EMPLOYMENT: https://www.skillsforemployment.org/KSP/en/Details/?dn=WCMSTEST4_033226

Ssekamtte, D. (2012). Why poverty interventions remain ineffective. Retrieved Sept 15, 2019, from https://www.monitor.co.ug/Business/Prosper/Why-poverty-interventions-remain-ineffective/6 88616-1435136-vw2utk/index.html

Ssewagudde, E. (2018). Why Small Medium Enterprises In Uganda Feel Neglected Despite Struggling To Survive. Retrieved May 20, 2020, from EABW News: https://www.busiweek.com/why-small-medium-enterprises-feel-neglected-despite-strugglingto-survive/

Taber, K. S. (2017). The Use of Cronbach's Alpha When Developing and Reporting Research Instruments in Science Education. Research in Science Education. https://doi.org/10.1007/978-94-6300-749-8

UNDP. (2015). Micro, Small and Medium Enterprises (MSMEs) as suppliers to Extractives Industry. UNDP Press.

Wickramatilake, R. M. (2018). Development of SMEs in Sri Lanka: Are we serious about SME classification? Retrieved Sept 10, 2019, from Daily FT: http://www.ft.lk/columns/Development-of-SMEs-in-Sri-Lanka---Are-we-serious-about-SMEclassification-/4-658337 


\section{Macrothink}

Business Management and Strategy ISSN 2157-6068

Wignaraja, G., \& Jinjarak, Y. (2015). Why Do SMEs Not Borrow More from Banks? Evidence from the People's Republic of China and Southeast Asia. Tokyo 100-6008, Japan: Asian Development Bank Institute. https://doi.org/10.2139/ssrn.2548916

\section{Copyright}

Copyright for this article is retained by the author(s), with first publication rights granted to the journal.

This is an open-access article distributed under the terms and conditions of the Creative Commons Attribution license (http://creativecommons.org/licenses/by/4.0/). 